\title{
Leaving Home Behind - Career Opportunity or Seeking for a Safer Life?
}

\section{A Study of Finnish and Estonian Migrant Women's Experiences of Immigration}

HELI HYVÖNEN, Researcher, M.Soc.Sc, B.Ed.

Department of Social Policy

University of Helsinki

\section{Abstract}

This article analyzes Finnish and Estonian women's perceptions of migration. The central questions are why women migrated from Finland to Estonia or vice versa, what expectations they had and how they first experienced the immigration. The data consists of 48 in-depth interviews. The starting point for the two groups was different and unequal; furthermore, the time of migration played a crucial role in the formation of their experiences. The majority of the Finnish women interviewed migrated in the $21^{s t}$ century, mostly for family or career reasons. Their expectations were rather negative and their main experiences were related to their roles: following a husband or creating their own careers. Most Estonians migrated to Finland in the early or mid-1990s, when the societal situation was very unstable and many wanted to leave the country to look for a better life. However, they first found life in Finland challenging.

Keywords: Finland, Estonia, female migrants

\section{Introduction}

Migration is a spatial phenomenon which arises when people move from one place to another. In international migration a person moves to a country other than his or her usual residence with the intention of taking up residence there for a relevant period of time (Hammar and Tamas 1997). A long-term migrant stays for at least a year and a short-term migrant between three months and a year (UN 1998). Migration might begin for a variety of reasons and may perpetuate across time and space (Massey et al. 1993). The experiences gained from living in the new environment often reshape the original plans for the duration of immigration. Migration has substantial effects on the migrant herself as well as both sending and receiving societies (Castles and Miller 2003.) 
This article analyzes Finnish and Estonian women as immigrants. The data consists of 48 in-depth interviews with women, who have migrated from Finland to Estonia or vice versa. At the time of interview they all were mothers; however, not all respondents had children at the moment of migration. The article aims to answer three questions: why these women migrated, what they expected and how they first experienced migration.

The first Finnish migrants moved to the rural forest sites of Sweden already in the early Middle Ages (Korkiasaari 1989; see also 2003). Before the World War I Finns had also migrated to the area of the former Soviet Union, the US and Canada. Compared with other Nordic countries Finnish emigration was male-dominated: almost $65 \%$ of migrants were men (Kero 1991). According to Varpu Lindström (1991; 1992), who has researched Finnish migrant women in Canada, their reason to leave (either alone, with their husbands or as "mail-order wives" to compensate the shortage of potential spouses) was to look for a better life, but often they ran into problems and had to live in harsh conditions.

The first Estonian immigrants were fortune hunters or seamen who jumped onto Russian sailing vessels in the $18^{\text {th }}$ century. Estonian immigration to the United States started in the late 19th century (Granquist 2006). Before that Estonians had migrated to the territory of Russia and Latvia (Kodakondsus ja migratsiooniameet 2004). The first significant wave of immigration came after the failure of the 1905 Revolution, and it brought a strong socialist contingent to the United States that led to the formation of many Estonian American Socialist and Communist organizations. After World War II, a large number of anti-Socialist and nationalistic Estonians escaped Soviet rule to Finland, Sweden, Germany and the United States (Granquist 2006). During Soviet rule (1940-1991) the borders were closed, and an ordinary person's opportunities to leave the country were very limited (Hansson 2005).

The migration patterns (and forms of migration) considered in this study are different for Finnish and Estonian women, because migration has taken place at different periods of time and partly for different reasons. Thus comparing the expectations and first experiences of the two groups provides a fruitful basis for exploring how the societal situation and the reasons for leaving affect expectations and experiences. The starting point for the research is interesting also because there are many similarities and differences between the two countries. First of all, they are geographically situated very close to each other: the distance between the capitals is only 80 kilometres. Second, the languages belong to the same language group and are mutually intelligible. Third, the histories have some similar traits: both Finland and Estonia have belonged to Russia and gained independence in 1918; however, Estonia was occupied by the Soviet Union from 1940-1991, while Finland succeeded in preserving its independence. 
Furthermore, Finland and Estonia differ as countries of emigration. The former represents a rich Nordic welfare state, in which the institutional model aims to provide a moderate standard of living, full social rights and gender equality for all citizens (Kandolin 1997). Traditionally the efforts of both spouses have been needed to sustain a family (Rantalaiho 1994; Korkalainen 2004; Julkunen 1994). However, the current child-care policy facilitating long care leaves has created a situation in which most mothers remain at home when children are under three years of age (Lammi-Taskula 2004).

When Estonia regained independence in 1991, it was economically and politically far less developed than Finland. During the early period of Soviet control many Estonians were deported to Siberia. Furthermore, Russians were in turn transferred to the country to work in new industries and fulfil the policy of russification (Raik 2004), whereby the country was ruled from Moscow. In the period of independence Estonia has rapidly been transformed into a democratic political system with quite a neo-liberal economy policy and has joined the EU in May 1, 2004. Although there have been attempts to return to the old gender roles, the income of the husband is usually too low to support the family alone and women have also worked outside the home (Narusk and Hansson 1999). Recently the Estonian government has started to develop welfare policies, for example, granting financial support to women who give birth (see Ministry of Social Affairs in Estonia 2006).

\section{Finland and Estonia as countries of immigration}

In 2005 there was a total of 113,800 foreigners living in Finland, of them about 15,000 were Estonians (56\% women) and they form the second largest immigrant group after the Russian (Statistics Finland). Over time, the reasons for and forms of Estonian migration to Finland have changed. In the 1980s migration took place because of specific job or family reasons (marriage to a Finn). In the 1990s the majority of immigrants have entered as (Ingrian) Finnish Returnees (Heikkilä 2006). This group, consisting of descendants (and their spouses and children) of Finns who had emigrated from Finland to Russia in the 1920s and 1930s were allowed to migrate to Finland after a statement by President Mauno Koivisto in 1990 (see Alien Law). Later also the descendants of the Ingrian Finns, who migrated to the rural area called Ingria (located partly in Russia and partly in Estonia) between 1600-1900 were allowed to migrate to Finland. Furthermore, there is a small number of people who have entered on forged or black market documents. (Jasinskaja-Lahti 2000, 18-19). This form of re-migration is often caused by an uncertain future in the present location, economic considerations or family reunification, and it exists also in other countries in Europe: ethnic Hungarians migrate from Romania to Hungary (see Gödri 2004), the Aussiedler policy in Germany allows the ethnic Germans (for example Jewish, Kurds the Kosovo 
Albanians and their children) to return to Germany (Koopmans and Statham 1999), and a large number of Greeks and their offspring from the US, Canada and Australia return to Greece (e.g. Niessen et al. 2005).

According to Jasinskja-Lahti and Liebkind (1997) the Estonians, the Finnish Returnees and Russian immigrants have the best potential to adapt well into Finnish society. However, both Estonian and Russian immigrants have had severe problems and faced obstacles in their integration (Liebkind et al. 2004). Many factors, such as the societal context and period of time have affected the experiences of migrants. Before the 1990s the employment situation in Finland was very good, but there were practically no special services for immigrants (Joronen 2005). In the 1990s the state began to develop different services to support the integration of immigrants; however, due to the economic recession, which hit Finland in the beginning of the 1990s, it was very difficult for the immigrants to become employed.

Including the Ingrians, there are about 10,000 Finnish residents in Estonia (Ahlqvist 1998; Kolomainen 2003). EU regulations do not require registration in another EU country if the migrant remains there for less than 3 months at a time. Thus, it is impossible to know the exact number of Finns in Estonia. According to the Finnish consulate in Tallinn, there were about 2,200 Finns who had declared to be living permanently in Estonia in 2005. They had migrated because of spouse's or their own career, family reasons such as marriage or in hope of a financially better future or after retirement. According to existing knowledge, there are very few re-migrants with Estonian family roots travelling from Finland back to Estonia (Tauriala 2005). There is no previous research on Finns having lived in Estonia.

\section{Women as immigrants}

On the global scale, women have always been represented in immigration. It might be true that more women are migrating now than ever before, but the most significant change has happened in the qualitative aspect-immigrant women have become more empowered, which means that more migration is taking place due to their own initiative in their own behalf (Engle 2004). Women have a significant role in all regions and most (though not all) types of migration. Gender roles have always been crucial in international migration although awareness of the topic has arisen only recently (Castles and Miller 2003). Until the late 1970s the role of women in migration was often ignored. If women's migration was analyzed at all, it was often conflated with the reasons cited for men. Furthermore, the experiences of women migrants were fitted into models originally created to understand, explain, and predict male migration (Kofman et al. 2000). Even today, policy makers do not consider women and men as equal agents in migration processes. For example, according to Finnish legislation, 
the officers at the border are to turn back women who are suspected of prostitution (Finlex HE 221/2005). The patterns are gendered and the social, political, economic, and cultural impacts are different for men and women, whereas the public discussion is often gender-neutral. Furthermore, "gender" seems to have replaced "woman" in the analysis (Erel et al. 2003).

Recent migration studies focusing on gender have mostly concentrated on unskilled female migrants or migrant women taking jobs in unskilled sectors of the labor market, particularly domestic work (Anderson 2000, as cited in Raghuram 2004). There has been scant acknowledgement of the presence of highly educated and skilled international migrant women in migration streams. However, not all women who migrate are disadvantaged and the entry into the labor market is not always limited to employment in poor markets. It is also important to note that migration has different implications for married women (with or without children) than for singles (Pedraza 1991). Moreover, the nature of family migration changes when the migrants are skilled and so the emerging patterns are much more complex than migration research commonly acknowledges (Raghuram 2004). For example, in Finland the pattern of women following their husbands and staying at home taking care of the children is slowly declining and nowadays husbands sometimes follow their wives. On the other hand, in families with two highly-skilled professionals the periods spent abroad are usually short - a maximum of a few years - especially if the other spouse does not succeed in finding a work at the destination (Ruckenstein 2004).

\section{Women - "tied movers"?}

In many cases women follow their husbands into another country, if he is the main breadwinner in the family; however, only members of certain categories of migrants are allowed to bring their spouses along (Erel et al. 2003).

A wife's decision to follow her husband's career nearly always harms her own labormarket status (Mincer 1978). This might be the case even when her socioeconomic status is higher than his. Most economic harm is usually experienced by mothers of small children, who often are subject to a sizable long-term absence from the labor force (Cooke 2003; Nivalainen 2002). Besides the sphere of employment, women's aspiration to migrate may also involve more personal factors such as quality of life (Raghuram 2004). According to Oksanen (2005), Finnish women who follow their husbands are often consistently homesick. They are forced to leave behind their own lives, work, social relations and sometimes even old parents, and they may feel guilty of preventing grandparents from having a close relationship with their grandchildren. Often the women also feel dependent on their husbands, especially in the economic sense, which causes a feeling of uncertainty, even fear. In sum, experiences of migra- 
tion affect women's lives on many levels: participation in the labor force, occupational concentration, religiosity, marital roles and satisfaction as well as autonomy and selfesteem (Pedraza 1991).

It is noteworthy that in Finland family migration is most likely to take place in the beginning of married life and when the children are small. It seems that a husband's career is often the most significant determiner in the migration decision-making process (Nivalainen 2002). This can be understood by Cooke's (2003) finding that family migration increases family income only among high-income families, where the husband is the primary wage-earner, since the positive effects of moving are associated with an increase in his income. On the other side, Marsden and Tepperman (1985) indicated in their study that migrant men tend to be gainers in the economic sense, while wives were nearly always losers.

\section{A decision to migrate - why do some go and some stay?}

Sassen's (1999) observations on migration are instructive: "Migrations do not simply happen. They are produced. And migrations do not involve just any possible combination of countries. They are patterned." The decision to immigrate cannot be seen simply as a matter of an individual's decision to search for better opportunities, otherwise there would be many more poor people emigrating to highly developed countries and the migration flow would not happen the other way. Instead, migrations are highly selective processes. Only certain people leave, and they usually travel on highly structured routes to predetermined destinations. Furthermore, there is interaction and interrelation between the sending and the receiving country (ibid.).

Typically, singles are more migratory than families (Mincer 1978). In Finland, it is more common for young women than men to migrate (Ruckenstein 2004). Sometimes women migrate alone leaving their families behind (Erel et al. 2003). The decision might be so independent that they inform the members of the household only after taking care of the practical arrangements (Phizacklea 2003). Thus, a decision to migrate can be seen as a question of power, which also might enable women to guarantee a better life for their families remaining in the native country (Erel et al. 2003). However, it is important to keep in mind that in many cases women may have few other choices. Furthermore, non-economic factors often play a crucial role. For example, migration can offer an opportunity to escape the oppressive structures to which women are subject in the country of departure (Kofman et al. 2000). To be able to understand the migration decision-making process, it is important to combine accounts of the structural context with the situational, micro-level aspects (Kofman et al. 2000). 
In her study of Chinese women migrating from rural areas to cities, Guifen Luo (2005), found that the family strategies played a crucial role in the migration-decision making process. Often the women migrated to be able to support their parents and in most cases they left their children in the care of their own parents. Luo also emphasized the importance of human capital during the migration. The women gained more independence, new skills and knowledge. Earning money gave them self-confidence and they received a voice on issues concerning themselves.

The general model of a migratory decision-making process (De Jong 2000) introduces the factors affecting the intentions and actual behaviour of migration. It was originally designed to be used with a quantitative data describing the migration from rural areas to cities in Thailand. I have added career-related ambitions, which are quite central in this study; furthermore, I emphasize the importance of gender roles in family migration norms (see figure 1).

Figure 1. General model of a migration decision-making process (De Jong 2000, modified by the author).

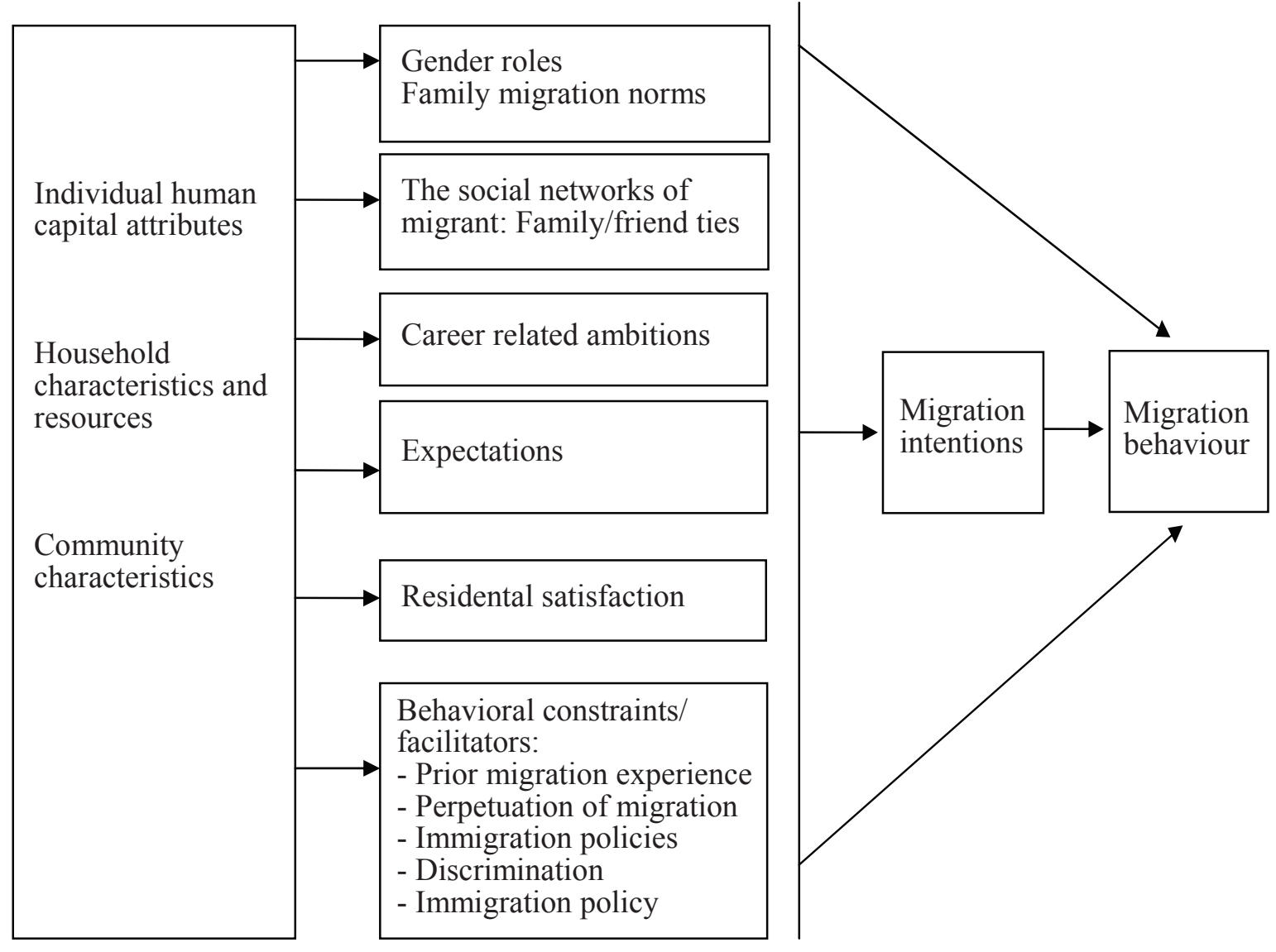




\section{Data and methods used}

The data consists of 48 (24 Estonian and 24 Finnish, see tables 1 and 2) in-depth interviews with women, who have lived both in Finland and Estonia. All Finnish interviewees were still living in Estonia, but two Estonians had returned to Estonia. The women had lived at the new destination from 1-15 years and the reasons and forms of migration varied. The most common reasons for Finns to migrate included husband's work and women's careers. According to Finnish legislation, a person (and his/her family), with a Finnish employer is entitled to the social welfare benefits of the Social Insurance Institute of Finland for the first five years even though living abroad (see Social Insurance Institution of Finland 2005).

To reach the potential interviewees, I sent a number of e-mails to various posting lists and used the snowball method. The interviews resembled long conversations (see Holstein \& Gubrium 1995) in which the respondents were given four themes; ${ }^{1}$ however, they were also free to bring up any topics they wished. The interviews were completed in 2005 and took place at homes, cafeterias, work rooms and public places such as libraries. ${ }^{2}$ The duration varied between one and two and half hours. Ten participants (eight Finnish and two Estonian) were interviewed for a second time in order to gain additional information about some themes, which were not discussed deeply enough in the actual interview. The initiative for the second round was in most cases mine; however, a few women brought up themselves their wish to give some more information. One Estonian and two Finnish women sent me e-mail after the interview with additional comments. In five interviews (three Finnish and two Estonian) the husband also participated at least part of the time. All the interviews were tape-recorded and transcribed. In May 2006, all the Estonian women were sent an additional question by e-mail about the assistance what they provided for and received from their relatives. Ten women replied by mail, two were interviewed by phone and two personally.

The analysis were completed by using the Atlas.ti coding program. In the first stage I read through the data several times, after which I coded and re-coded it, combined the codes and built different code families. Relying on them I reconstructed the most central notions for categories presented in this article. To support the actual analysis, memos were made throughout the process (Charmaz 1994; Dey 1999). The ethics were considered carefully: first and foremost, participation was voluntary, and most interviewees seemed to appreciate that the interest shown in their lives, and had a desire to share their experiences (Kortteinen 1982). Nonetheless, I felt that the Finnish

1 The themes were: migration and life in a new country, social networks, the process of becoming a mother and the comparison of the two countries.

2 Sixteen of the Finnish women interviewed were currently living in Tallinn (three of them had lived in Tartu before), six were living in Tartu and two in a small town. The majority (22) of the Estonian women were living in the capital region and two in the Turku region. Two Estonian women had lived in a small town in Finland before. 
Table 1. The reasons and forms for migration from Finland to Estonia

\begin{tabular}{|c|c|c|c|c|c|}
\hline & \multicolumn{4}{|c|}{ Reasons of migration } & \multirow[b]{2}{*}{ Total } \\
\hline & $\begin{array}{l}\text { Husband's } \\
\text { career* }^{*}\end{array}$ & Own work & Own studies & Marriage & \\
\hline Persons & 11 & 6 & 5 & 2 & 24 \\
\hline Time in Estonia & $1-5$ years & $1-10$ years & $1,5-9$ years & $6-7$ years & $1-10$ years \\
\hline $\begin{array}{l}\text { First child before } \\
\text { migration }\end{array}$ & 8 & 4 & 0 & 1 & 13 \\
\hline $\begin{array}{l}\text { First child after } \\
\text { migration }\end{array}$ & 3 & 2 & 5 & 1 & 11 \\
\hline \multirow{2}{*}{$\begin{array}{l}\text { Previous } \\
\text { experiences in } \\
\text { Estonia }\end{array}$} & \multirow[t]{2}{*}{ Studies: 1} & Studies: 1 & & & Studies: 2 \\
\hline & & Work: 1 & & Work: 1 & Work: 3 \\
\hline \multirow{3}{*}{$\begin{array}{l}\text { Previous } \\
\text { experiences of } \\
\text { living abroad }\end{array}$} & Studies: 1 & Studies: 2 & Studies: 2 & & Studies: 2 \\
\hline & Work: 1 & Work: 1 & Work: 2 & & Work: 3 \\
\hline & $\begin{array}{r}\text { Husband's } \\
\text { work: } 5\end{array}$ & & & & $\begin{array}{r}\text { Husband's } \\
\text { work: } 5\end{array}$ \\
\hline \multirow[t]{3}{*}{ 'Home country'** } & \multirow[t]{3}{*}{ Finland: 11} & Finland: 2 & Finland: 3 & Uncertain: 2 & Finland: 18 \\
\hline & & Estonia: 2 & Estonia: 1 & & Estonia: 3 \\
\hline & & Uncertain: 2 & Uncertain: 1 & & Uncertain: 3 \\
\hline \multirow[t]{3}{*}{ Skills in Estonian } & Fluent: 4 & Fluent: 6 & Fluent: 5 & Fluent: 2 & Fluent: 17 \\
\hline & Rudimentary: 5 & & & & Rudimentary: 5 \\
\hline & No skills: 2 & & & & No skills: 2 \\
\hline \multirow{3}{*}{$\begin{array}{l}\text { Age at the } \\
\text { migration }\end{array}$} & Under 20: 0 & Under 20: 0 & Under 20: 2 & Under 20: 0 & Under 20: 2 \\
\hline & 20-30: 6 & $20-30: 2$ & 20-30: 3 & 20-30: 1 & 20-30: 12 \\
\hline & Over 30: 5 & Over 30: 4 & Over 30: 0 & Over 30: 1 & Over 30: 10 \\
\hline
\end{tabular}

* The husbands of eight interviewees were expatriates, highly skilled professional workers, who had been transferred by their companies to work in Estonia for a determined period of time. One husband was working for a non governmental organization and two husbands were private entrepreneurs.

${ }^{* *}$ By 'home country' is meant the women's own opinion of what they felt was their primary home country.

women were often more willing to share their life with me as a researcher than the Estonian. For example, one Finn stated: "I think that everybody's opinion is that it is only positive that you are here [in Tallinn]." Second, the interviews were confidential and the anonymity of the interviewees was retained by pseudonyms and by changing all recognizable factors in this article. The quotations used are also selected in order to avoid recognition.

\section{Moving to Estonia: "So close, and still so far away"}

Now I will introduce the expectations and experiences of the Finnish women who migrated to Estonia. Of the 24 women interviewed, 11 had followed their husbands, 11 were establishing their own careers, and two left for family reasons (see Table 1). Most 
Table 2. The reasons and forms for migration from Estonia to Finland

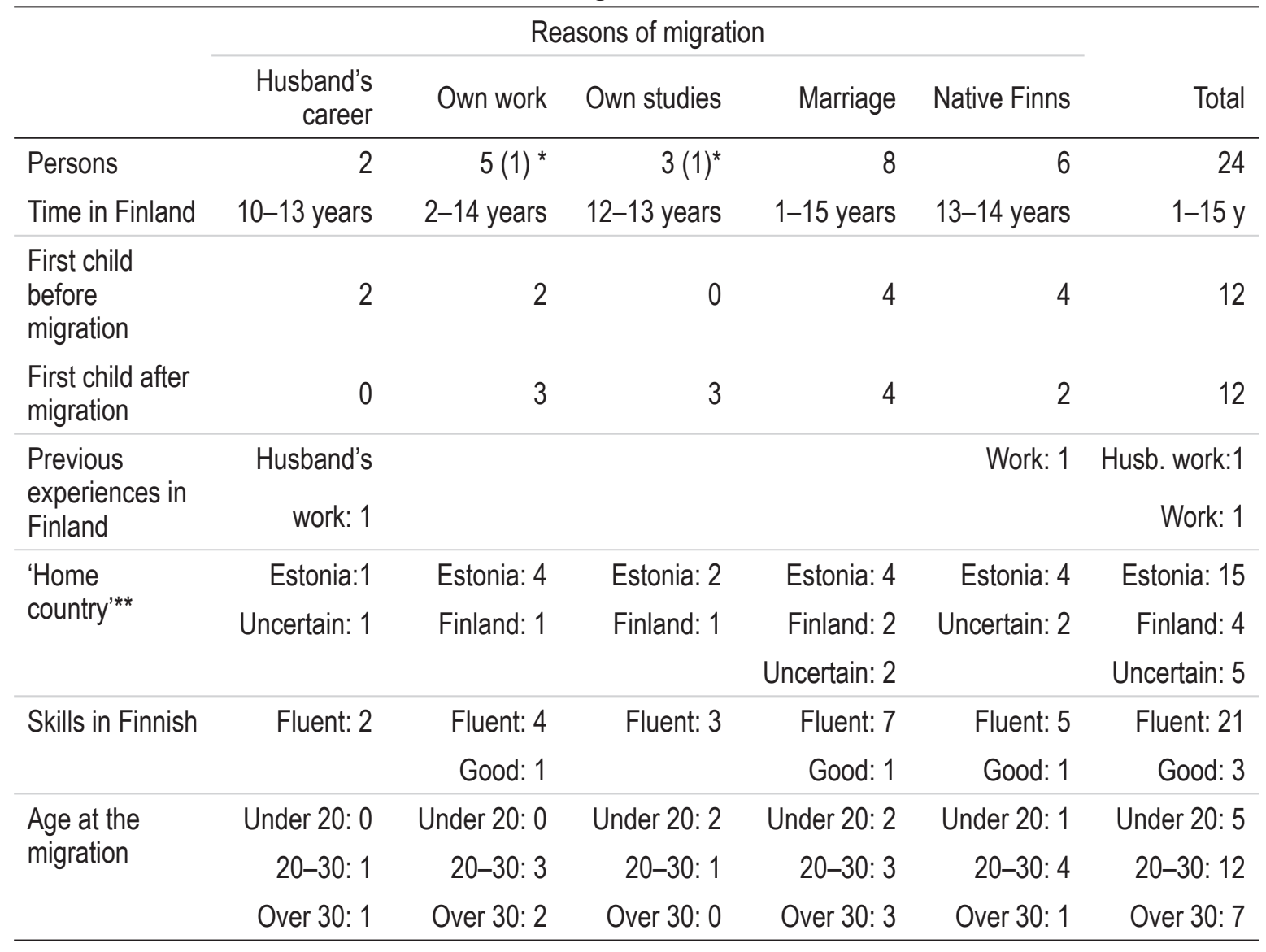

${ }^{*}$ Two Estonians had returned to Estonia at the time of the interview.

** By 'home country' is meant the women's own opinion of what they felt was their primary home country.

(19) women were originally planning to remain for a set period of time. The first two women migrated before the mid-1990s, when the societal situation was still uncertain and everyday life quite complicated. Seven women migrated between 1995-2000 and fifteen after 2001 (see Table 1), when the situation had already started to stabilize to the extent that everyday items were widely available in stores. Thirteen women had their first child before and 11 after their migration. The women's expectations were quite contradictory. On the one hand the new country, culture and language were appealing, on the other, relocation was somewhat frightening:

- $\quad$ "My first reaction was that no way... I'm not going to move to Estonia. (laughs). [---] ... it was that this is like a developing country and I won't go there under any circumstances. My thought was that it would be like going to Russia." (Emmy, age group 25-30, vocational training, 31/2 years in Estonia; husband's career) $-(1)$

- $\quad$ "I read an article about this place in a magazine [---] Finnish students had written it, and it sounded like the coolest in the world [---] and I was like YES!' (Siiri, age group 30-35, high-school, 9 years in Estonia; own studies) - (2) 
Both quotes reflect how little known and exotic Estonia was to average Finns, despite the geographical proximity. All the women visited Estonia at least once before the actual migration and eight of them had spent a longer period of time there, studying, doing volunteer work or visiting friends. Thus, the women had a somewhat a realistic picture of life in Estonia before moving, although they mentioned some disappointments. Besides their own previous experiences, women received information about the country, its customs and ways of life from their Finnish and Estonian networks (see LukkarinenKvist 2006; Ågren 2006). None of the women mentioned having watched Estonian TV, which could be seen in some parts of Finland. Those women, who had not visited the country since the beginning of the 1990s, expected everything to be unchanged and the society to be still little developed. None of the women saw Estonia as the destination of their dreams; quite the contrary. Their outlooks were rather prejudiced, and they were concerned with challenges of everyday life, for example the lack of daily groceries, fear of bureaucracy, and the high rate of criminality.

- $\quad$ "I had actually been here once when it was still was under Soviet rule. And at that time it was really different....there was nothing. At the grocery stores there was like Coke and meat... and the apartments were what they were, I was living with a family. And when I left to come here, I had five packets of tampons with me and all the basic things in my bag, because I thought that there was nothing here." (Laura, age group 30-35, university degree, 6 years in Estonia; student) - (3)

The prejudices, such as fear of insecure surroundings, were emphasized especially in the interviews with mothers of small children. They were concerned about how their children would adapt in the new surroundings and whether they would feel and be safe. Also having to leave the social networks to Finland caused apprehension (see Oksanen 2005).

- $\quad$ "Well, in the beginning when we left and came here, I imagined roughly, that the car would be stolen from the street the very first night. [---] I still have a kind of feeling of insecurity, for the children's sake, that... if I let them go to the toy section at the department store and go around in peace by myself, well that is okay... But in the beginning I didn't dare to leave them anywhere. [---] But there is no way that they could be left in the car here." (Camilla, age group 35-40, university degree, 1 year in Estonia; own work) - (4)

For a few women, migration was a way to escape Finland. Their reasons to leave varied, but they shared a desire to leave the native country behind because they were bored with a too secure and steady society and wished to see something else and seek challenges. Three women mentioned that they wanted to distance themselves mentally from their parents (see Erel et al. 2003). 
- $\quad$ "I had some kind of mother complex myself (laughs) [---] In other words, my mother was really dominant. She wanted to have a key to my house; she opened my mail and everything. And I realized that when I started getting closer to forty, I had to get away from my mother. And I couldn't see any other way [than immigration], because I still wanted to have a good relationship with her." (Karoliina, age group 40-45, vocational training, 41/2 years in Estonia; adventure) - (5)

\section{"The first few months were quite a dark time"}

Moving to a lower-wage country but still being able to maintain or even increase the income level of Finland, which was the case for almost all, is empowering. However, nearly all interviewed women experienced the initial period as being challenging due to the lack of social networks, an inability to communicate in Estonian and the confusion caused by a foreign society and its customs (see Lukkarinen-Kvist 2006; Ågren 2006). Especially women who had migrated because of their husband's job, expressed feelings of loneliness and wished to spend more time with their spouses. The lack of other social networks was also pointed out. The Finnish women experienced the local people as being somehow distant in the beginning and thought that it was hard to establish a contact with them (see Oksanen 2005).

- $\quad$ "The adaptation was most difficult during the first half year. At that time I was terribly homesick. [---] One [Finnish] lady told me that it all sounded familiar, that in the beginning you have such feelings, but after a while she started getting on well here. I thought that oh no, I don't believe that such a stage will come. But it took a bit over half a year and little by little I started getting on well here." (Aliisa, age group 30-35, college education, 7 years in Estonia; marriage) - (6)

Living in new surroundings caused uncertainty and feelings of being an outsider. Nearly all the women mentioned having experienced some type of a culture shock. It appeared when women realized the real situation of their surroundings, that is, when the fascination changed to confusion (see Järvinen-Tassopoulos 2005).

- $\quad$ "Well... when I decided that I'd stay for a longer period of time [---], then came the culture shock (laughs), which hadn't come before that. [---] So then ... then came the feelings of noticing the negative sides of the society. Until that I had somehow related really positively to everything... like discovering... Well... like a tourist in the beginning." (Marleena, age group 30-35, university degree, 5 years in Estonia; own studies) - (7)

However, after getting over the culture shock and growing familiar with the new society, the Finnish women experienced living in Estonia as a pleasant undertaking. 
Especially in Tallinn, daily life reminded them of the familiar patterns in Finland: it was possible to buy Finnish groceries at the market, all the Finnish TV programs could be watched and the Finnish social network was intensive. Even the culture and climate were similar. Thus, the major determinant of the experiences was the role of women - whether they had migrated in order to develop their own careers or support their husband. Furthermore, the timing of migration in the family life-span was crucial: women either followed their husbands and stayed at home or migrated as singles to establish their own career. Only one husband had followed his wife and even he was able to retain his job by telecommuting (see Ruckenstein 2004; Mincer 1978; Cooke 2003; Nivalainen 2002).

- "Well, actually, the setting functions so that he distance works... does the same job, which he did in Finland... [---] so that in that sense it is quite an easy situation." (Camilla) - (8)

\section{“It really doesn't matter where you are at home"}

Eight of the 11 Finnish women, who had followed their husbands, had (at the time of migration) at least one child under three years and three women had their first baby during the first year in Estonia. Nine of these women were entitled to the Finnish social welfare benefits (practically speaking, they were on care leave), just as they would have been in Finland (see Social Insurance Institute of Finland 2005). Thus, the situation released the women from having to return to work before the youngest child turn three years, and they were satisfied with the option of taking care of the children at home. It didn't seem especially important whether they stayed at home in Estonia or in Finland. However, it is noteworthy to mention that there is not any strong housewife culture in Finland and it is quite uncommon for women to remain at home after the youngest child has turned three (see Oksanen 2005; Ruckenstein 2004).

- $\quad$ "I was on maternity leave, like quite many of those who come here are. I had done some studies besides working and then I thought that now would be a good time to go [to Estonia] and on the other hand it is in a way good to stay at home for a while; and I could also finish up my studies. " (Isabella, age group 30-35, vocational training, 11/2 years in Estonia; husband's career) - (9)

\section{"I was only happy to stop working"}

The two women whose husbands were private entrepreneurs in Estonia and who were not entitled to the Finnish social welfare benefits of Finland (but were still forced to leave their own work in Finland) indicated that not having to work was a new and 
warmly welcomed experience (see Oksanen 2005; Ruckenstein 2004). Both women had low levels of education. One had had many jobs in Finland and the other was quite unsatisfied with her work.

- "Well, I had worked a hell of a lot, so that it was... let's say that before I had children I had three different jobs... [---] so I really had a lot of work... so when I left the jobs and started my career as a housewife, it felt like a luxury, totally [---] It felt like a vacation... Now I go for a vacation and it is long..." (Airi, age group 45-50, no education, 41/2years in Estonia; husband's career) - (10)

\section{"Giving up my career was really hard"}

Two women said that they had to give up their own careers to support their husband's careers (see Oksanen 2005; Ruckenstein 2004). For the one, her husband's work assignment had continued for several years and her family had already lived in two other countries. Both women expressed bitterness at having to leave their own jobs after having achieved certain goals; however, the other one was working and studying in Estonia (see Marsden and Tepperman 1985; Cooke 2003).

- $\quad$ "Well, we had talked about it. I thought it was nice to play around with the idea, but when my husband came home one day holding an A4 in his hand stating that he had permission to move, so at that stage I almost started crying (laughs). [--] I had finally achieved what I had wanted... I had a nice job, which I loved." (Maarika, age group 30-35, vocational training, 1 year in Estonia; husband's career) $-(11)$

\section{"Estonian society offers so many challenges"}

Six of the interviewed women had migrated because of their own work and five did so for their own studies. The students sought variety or took advantage of the fact that access to the university is easier in Estonia than in Finland. Those who worked were looking for a better position and/or a more challenging job (Ruckenstein 2004). Women experienced studying and working in Estonia as interesting and challenging tasks; however, they did mention that the language caused difficulties. In general, women of this group perceived their role as being that of active participants and felt that they had managed to gain real contacts in Estonian society (see also Mincer 1978; Ruckenstein 2004; Erel et al. 2003).

- $\quad$ "When I moved back to Finland, I had a feeling of 'good-bye Estonia', that, I will never come back. But after we had stayed for a little while in Finland, then I started thinking that I will never go back to Estonia. [---] I had decided that I 
won't drag a small child there, that now we will live in Finland [---] It is much safer and everything... [---] But then one job was announced here and I applied for it. And actually I didn't even need any long consideration. Instead, it came immediately that this is my place." (Meri, age group 25-30, university degree, $5+1$ years in Estonia; own studies) - (12)

To sum up, the Finnish women migrated in most cases either alone to create their own career (single persons) or with their families to support their husband's careers (married women) and originally for a set period of time. Their expectations were quite contradictory and many met difficulties in the beginning, but after having settled down they liked their life in Estonia. Their experiences were much affected by whether they worked or stayed at home.

\section{The starting point for migration to Finland: "A retreat from Estonia"}

The starting point for the Estonian women was very different than the Finnish. This can be explained by the social situation and the lack of financial resources (Hansson 2001). Of the 24 women interviewed, eight migrated for family reasons, eight wanted to establish their own careers, six returned as naturalized Finns and two moved because of their husband's careers. Half of the women had at least one child before migration and the other half afterwards. Two of those who were interviewed had migrated as teenagers, thus they were not independent decision-makers. The time of migration played a crucial role in the women's expectations and experiences. Until the mid-1990s, the societal situation in Estonia was very unstable and there was a lack of everyday items, which made life very difficult and social networks were sometimes essential for satisfying basic needs (Hansson 2001; Lie and Malik 2006). Many people had a desire to leave the country and 18 of those interviewed migrated during that time.

- "Well, we really had a good situation, because my grandmother was working in a seaman's hospital [---] She was in charge of the food store, so she had the possibility to always get good food and so on... And we had a Finnish step-father, he of course got us clothes and all that stuff [from Finland]. [---] The thing was that even though you had money, but no relations, you basically had nothing. [--- ] So in that sense we were quite well off." (Liis, age group. 25-30, high school, 16 years in Finland; mother's marriage) - (13)

- $\quad$ "When I came to work in Tartu in 1992, at that time you still needed coupons to get bread from the store... and there was a long line in front of the door.You had to go to the end of the line in order to get something. Something good. [---] 
That something had arrived in the store, for example toilet paper." (Sirpa, age group 40-45, university degree, 7 years in Estonia; marriage) - (14)

Thus, it is obvious that the women sought both mental and financial security from their environment. Independent of the official reason for leaving, the main cause was very often expressed as having become tired of the continuous uncertainty (Lie and Malik 2006). The most important issue for the women was the opportunity to leave the country, and Finland was an easy and adequate destination.

- $\quad$ "You had to get married - a shotgun marriage. You were forced to get married to get out of there [Estonia]. And the father wanted, of course, to live with his children. So I was forced to get married, because otherwise I wouldn't have got out of there." (Kristi, age group 40-45, no higher education, 14 years in Finland; marriage $)-(15)$

Women with children often said that immigration considered best for the child. They wished that their children could grow up in a peaceful environment. They also wanted to guarantee them better opportunities, such as a higher quality education (see also e.g. Huttunen 2006; Lukkarinen-Kvist 2006; Ågren 2006).

- $\quad$ "Well, when I think afterwards, it was that I wanted to be somewhere in peace, that I wouldn't have to worry everyday, well at least not so much..." (Pille, age group 45-50, university degree, 3+8 years in Finland; husband's career) - (16)

Excluding the marital migrants, migration was originally seen as a temporary solution to achieve a quieter and calmer life. It was an experiment, and a very important coping strategy was to keep in mind the option of returning to Estonia, if life in Finland turned out to being impossibly difficult (Lindström 1991; Lukkarinen-Kvist 2006; Ågren 2006).

- $\quad$ "[In Estonia] we didn't have furniture, not to mention anything else. But we were quite satisfied. [---] But when our child became quite seriously ill we decided that because life offered at that moment the option of moving somewhere else... We were young and brave and we decided, why not try. If we don't like it, we can come back. My mother and father lived there and we still have an apartment in Tallinn." (Klarika, age group 40-45, university degree, 14 years in Finland; a Native Finn) - (17)

Nearly all interviewees mentioned that the women supported their parents and other relatives in Estonia (see also Luo 2005). The Estonian women were sent an additional question by e-mail about the forms of support. Among the 14 answers received, the most 
common means of assistance were bringing presents such as food, clothes, domestic appliances and special supplies needed for hobbies from Finland (cf. Vertovec 2004; Zechner 2002). Some women mentioned that they felt happy giving presents, but felt bad when some, especially elder relatives, wanted to compensate them. However, none of the women mentioned that the wish to support relatives was their major reason for leaving.

Even though the situation in Estonia was oppressive for many families, not all women were eager to leave the country (Lie and Malik 2006). They felt it was difficult to leave everything behind and move to a foreign country, even though they longed for more peaceful surroundings (see also Luo 2005).

- $\quad$ "Well I wouldn't have wanted to move in the beginning. Because then my opinion was, that I didn't want to move to any country, where I didn't know the language. It is such a feeling of being an orphan..." (Sirje) - (18)

In part the Estonian family migration norms were different from the Finnish. The women migrated either as singles (because of having married a Finn or to establish their own careers) or with their families. However, the Finnish Returnees often migrated together with their whole (extended) families. They also often had an existing network in Finland, consisting of other Finnish Returnees, who had migrated earlier (Reuter and Jaakkola 2005; Heikkilä 2006). By contrast, one woman migrated alone and her husband stayed in Estonia.

- "Actually my aunt asked me [to come with her] then. [---] She had a son [---] but he didn't want to go. [---] my brother came along too. [---] And my sister came half a year later. [---] And then my parents came at some point." (Ûlle) - (19)

After the situation in Estonia stabilized, migration assumed a different significance for the women. Six of those interviewed had migrated in the $21^{\text {st }}$ century and the starting point for them as migrants was much different from those who had migrated earlier. Also they were expecting a better life, but in a different sense.

- $\quad$ "I can't even say whether I had any expectations. In my opinion the most important thing was that I had a job and that... only that I have a job and I get my salary, so that I can live a normal life. [---] But also because I wanted to do exactly this job, and nothing else, and it was in general very difficult to find a job in Estonia, so... I really had to come." (Sofi, age group 40-45, vocational training, 2 years in Finland; own work) - (20) 


\section{"I already knew quite a lot in advance thanks to Finnish TV"}

All except two of the interviewed women had visited Finland before migration at least once. Most women also had a large number of relatives and/or friends, who were familiar with Finnish society (see Reuter and Jaakkola 2005; Heikkilä 2006). Thus, they had heard stories and seen pictures of the country. Seven of the women had remained in the country themselves for a longer period of time, for example, visiting friends and relatives or working in the summer. For those who married a Finn, migration was also (mentally) a long process, because there was a period of dating before the marriage, which lasted usually at least two years. Four of the women had migrated to Finland at least twice. Besides previous experiences of visiting Finland, the Finnish media presents its own picture of the country. Finnish TV could be seen in the Tallinn area and Finnish women's magazines were sent by relatives and friends.

"My grandmother's friends sent Anna and Kotiliesi magazines to her. [---] Once I had them at school with me, and they were torn from my hands (laughs). Even the teacher asked me if she could have a look at the magazine." (Maria, age group 30-35, university degree, 11 years in Finland; own studies) - (21)

\section{"Life in Finland was so hard in the beginning"}

All Estonian women, independent of the reason for or the time of migration, met many difficulties in Finland during the initial stages (see also Jasinskaja-Lahti and Liebkind 1997; Zechner 2002). For those who migrated to escape the difficult Estonian situation in the 1990s, Finland offered the secure and calm environment desired, and even a minimal living for some groups. However, life in the beginning was experienced as very challenging. The greatest problem was financial (see also Lindström 1991).

- $\quad$ "It really was hard in the beginning. I can't help that. [---] It was Monday and I had 40 marks for that week. I knew that the school food cost ten marks, so that I would have money for food for four days, but that one day I'd have to go hungry, because I didn't have money to buy food." (Maria, age group 30-35, university degree, 12 years in Finland; own studies) - (22)

The financial problems of the immigrants were emphasized by the worsening economic situation in Finland. In the beginning of the 1990s, the economic recession was just starting in Finland, causing vast unemployment in the country. Thus, it was very difficult for foreigners to find jobs (Joronen 2005). The lack of work (or other reasonable daily activities) caused frustration and negatively affected their self-esteem and the women easily felt worthless in the new society. It was an especially difficult situation 
for those women, who had had a good working position in Estonia before their immigration (see also Nivalainen 2002; Luo 2005).

- "My husband got a job and I felt that I wasn't beneficial for this society, because I couldn't do anything significant... I didn't have a job and I received money from the social office; it really made me feel ashamed because I wasn't any good... when I didn't have any friends and it really was such a hard moment." (Klarika, age group 40-45, university degree, 14 years in Finland; a Native Finn) - (23)

- $\quad$ "In Estonia I was doing quite well... I was working as [occupation] and I was offered a quite nice job in a couple of different places. And then I voluntarily came to Finland to be unemployed without any future... (Jane) - (24)

Ten of the women came from outside the Tallinn area and did not speak Finnish. They found it difficult to get along, because they were not able to communicate with Finns and they felt like outsiders, and it was very hard to get to know people (see also Lukkarinen-Kvist 2006; Ågren 2006).

- "I really felt like a stranger... the school should have taught more Finnish" (Tiiu, age group 20-25, vocational high school training, 13 years in Finland; a Native Finn) - (25)

The feeling of loneliness in the beginning was mentioned in nearly all interviews. Also those women who knew Finnish and migrated with their family or relatives described their feelings of isolation during the initial stages (see also Oksanen 2005).

- $\quad$ "The beginning was kind of a difficult because I didn't have any friends... I missed social intercommunication. Well, in Estonia I was used to living in a certain way... and then, in a way, I had to start everything all over..." (Ûlle, age group 30-35, vocational training, 13 years in Finland; a Native Finn) - (26)

The loneliness appeared not only in relation with other people, but also in relation toward the society. The diversified services and requirements were confusing and a few mentioned having wished for some help in organizing their everyday routines as well as processing of all kinds of official paperwork.

- $\quad$ "The language was there, but I spoke it badly. So I ached for more personal assistance... which I would have needed. But I got along. " (Marta, age group 45-50, vocational high school training, 14 years in Finland; a Native Finn) - (27) 
It was also brought up that the complicated and time-consuming procedures of the society, such as applying for a residence permit, made the interviewees feel miserable. At the individual level, the action seemed bureaucratic and made women feel like second-class citizens without any rights (see also Phizacklea 2003).

- $\quad$ "And the queue was half a year, the line to renew the residence permit. And passports were taken away, you couldn't go anywhere. That made me feel very oppressed, really. [---] You can't go anywhere, you are alone. [---] I cried a lot. [---] And that's why I went to the university and started working as soon as possible, 'to get out of the imprisonment'. '" (Enely, age group 30-35, university degree, 14 years in Finland; a Native Finn) - (28)

To sum up, most of the Estonian women migrated in the beginning of the 1990s, when the social situation was very unstable in Estonia. Not depending on the official reasons of migration (marriage, Finnish returnee, furthering career or following a husband) they were looking for a more peaceful and safer life in Finland. For women with children, the migration was undertaken to improve life for children as well. Excluding the marital migrants, migration was originally seen as a temporary solution. All interviewees found the initial stages in Finland difficult; however, most of them experienced living in Finland as a satisfying undertaking.

\section{Discussion}

This article has focused on analyzing the reasons of Finnish and Estonian female migrants as well as their expectations and first experiences of immigration. According to Lindström (1991) it is difficult to describe the characteristics determining whether a woman decides to leave or to stay and how she experiences migration. However, it can be stated that the women who actually leave their country of origin are often exceptional, since they form only a small percentage of the total population (see also Sassen 1999).

De Jong (2000) has searched for an answer to the question above in his model of migration decision-making (see Fig. 1). Considering his model it seems that the most significant factors affecting Finnish women's migration to Estonia were individual human capital attributes, family migration norms and career-related ambitions. The former refers to furthering one's own career achieving a better position in their careers or being able to enter to aspired education more easily than in Finland. By contrast, the women who stayed at home missed out on these opportunities to gain work experience (see Cooke 2003; Nivalainen 2002). However, most of latter mentioned justified home making and said they were grateful for this option. Even though the pension does not 
accumulate during those years, they called these the best years of their lives. As Luo (2005) found in her study that migration and the capability to cope in a foreign society improved the self-esteem of women as well as offered new experiences. However, for the woman following her husband's career means being dependant, and can also have negative effects on self-esteem (see Nivalainen 2002; Oksanen 2005; Cooke 2003; Marsden and Tepperman 1985).

The second factor affecting the Finnish women's migration decision is gender roles and family migration (see Nivalainen 2002; Ruckenstein 2004). Often migration was a question of timing in the family life-span: women migrated either alone or followed their husbands; only one husband in the study followed his wife. The latter confirms the traditional male-breadwinner model and puts women somehow in a dependent situation, in which they are not necessarily independent decision makers. By contrast, singles do not have such restrictions and are freer to carry out their will. Furthermore, the starting point differed depending on whether the migrant was a 20 -year-old student or a professional following her husband with a family consisting of five members. Most of the women who followed their husbands were entitled to parental leave and thus they did not have to give up their career totally, for most of women were able to maintain their workplace in Finland. However, two women had to give up their own work and they were rather bitter about that. Thus, migration also raised the question of whether women wanted to concentrate on developing their own career or supporting their husband's careers (see Oksanen 2005).

Estonian female migration, for its part, was affected most by community characteristics, immigration policies, household characteristics, and expectations (see Fig. 1). Especially in the beginning and during the mid-1990s, when the societal situation was unstable, the primary reason for Estonians to come to Finland was the desire to leave their country of origin (a community characteristic). Finnish immigration policies made it possible for Finnish returnees, who formed the largest immigration group, to enter Finland (immigration policy). On the contrary, the immigration policy for other groups was experienced as being rather strict and in some cases it required considerable resources and effort to achieve the permit to enter the country.

For the Estonian women, expectations of a better and more economically and environmentally stabile life, or as one respondent put it, "normal life" in Finland, were in a central role in decision making. Also the desire to see other places was emphasized because the borders of the country had been closed and only one woman had lived abroad before migrating to Finland (Hansson 2005). Additionally, only a few had visited any other western European country. The expectations of women were to a large extent based on the Finnish media and the stories they had heard about the social network and thus not necessarily realistic (see also Lukkarinen-Kvist 2006; Ågren 2006). This might 
have influenced the first years, which were experienced as being difficult (Lindström 1991). The women appeared to be more or less on the same footing independent of the reason for leaving. They shared a desire to leave their country of origin in hope of a better life. It is interesting that even though the situation has improved drastically in Estonia and is to a large extent different from the 1990s, women who have migrated in the $21^{\text {st }}$ century have still looked to their lives in Finland. This can partly be explained by the lower salaries in Estonia and persistent poverty among several social groups. However, they have met with many similar difficulties in Finland as those who migrated earlier (see also Lindström 1991).

Among the Estonians also the importance of household characteristics and resources was emphasized. First of all, due to the poor economic situation in the 1990s, not everybody had the financial resources to leave (see Lie and Malik 2006). Thus, the migrants who actually could enter Finland were a select group. Second, the social networks, especially close relatives, were very important during the Soviet period, and thus only those people who did not have responsibility for care of their own parents could leave (see also Zechner 2006).

One way to look at female migration between Finland and Estonia is to consider the degree of intentionality. Since the vast economic and social hardship in Estonia, the migration of Estonian women had many similar traits with forced migration (in which people are forced to leave their home countries because of persecution, human rights abuse or generalized violence (Castles and Miller 2003)). However, none of the interviewees brought up having been intimidated or oppressed by state functionaries or the majority community. Thus, the migration from Estonia to Finland cannot directly be seen as forced. However, migration may have provided some women a change to come out of the hard situation and develop a way to become self-sufficient (Siddiqui 2003). On the contrary, for the Finns, the motivations were primarily economic or related to family reunification or marriage. Even in the case of the former it has to be kept in mind that no migration can ever be adequately understood solely on the basis of economic criteria (ibid.). In addition, it is possible that in some cases the Finnish women did not have an explicit choice whether they wanted to follow their husbands (Oksanen 2005).

It is interesting to note that half of the Finnish women interviewed had established their own professional career and that only two Estonian women came to Finland as au-pairs. Of the three others Estonian women who migrated in search of their own careers, two had a university education at the time of migration. In that sense migration may have ensured the women better options than if they had stayed in Estonia, due to the generally higher living standard in Finland (see Erel et al. 2003). The Finnish women in the same situation, especially those following their husbands, were far 
from average women in the economic sense (see also Lindström 1991; Sassen 1999). Thus, after all, migration offered both Finnish and Estonian women chances that they probably would not have had in their countries of origin.

\section{Conclusion}

This article's title "Leaving home behind - career opportunity or seeking for a safer life?" summarizes the characteristics of Finnish and Estonian female migration. The 24 interviewed Finnish women migrated to Estonia because of husband's (11) or her own career (11) or family reasons (2) mainly in the $21^{\text {st }}$ century. Some of them were really excited about the special features of life in Estonia, but most of them feared the difficulties in everyday life such as availability of daily groceries and a high crime rate. Furthermore, they were looking for opportunities to achieve such positions that they could not attain in Finland. The Estonian women migrated to Finland mainly in the beginning of 1990s to escape economic and social hardships and to guarantee a better future for their children. The official reasons were: marriage with a Finn (8), career (10) and returning as a Native Finn (6). They were looking for a more peaceful life and a calmer environment.

The starting point of the Finnish women was much more empowered than that of the Estonians. First of all, their financial resources were better and thus they had more options to organize their lives in a satisfactory manner and find solutions for the difficulties in the beginning. They were also less dependent on the Estonian state than the Estonians were on the Finnish state, which gave them more mental and physical freedom. However, they had fewer language skills and they did not integrate into Estonian society. Unlike the Estonians, at the time of migration, they had a position (either a job transfer or a place to study) in Estonia, while for many Estonians migration was rather like a leap into the dark. This can explain why the Estonians experienced the initial period as much more difficult. Furthermore, due to the lower living standard in Estonia than in Finland, migration put the Finns into better financial positions - in contrast to the Estonians, who nearly without exception faced financial difficulties upon arrival.

\section{Acknowledgements}

I thank Leeni Hansson, Anna Rotkirch, Ismo Söderling and an anonymous Referee for their comments of this article, which is part of the REFER research consortium finaced by the Academy of Finland (208186). 


\section{References}

Anderson, Bridget. 2000. Doing the dirty work? London: Zed Press.

Castles, Stephen and Mark J. Miller. 2003. The Age of Migration. International Population Movements in the Modern World. New York: The Guilford Press.

Charmaz, Kathy. 1994. The Grounded Theory Method: An Explication and Interpretation. In: Glaser: Barney G. (ed.): More Grounded Theory Methodology: A Reader. Mill Valley, CA: Sociology Press.

Cooke, Thomas J. 2003. Family Migration and the Relative Earnings of Husbands and Wives. Annals of Association of American Geographers 93(2): 338-349. Blackwell Publishing.

De Jong, Gordon F. 2000. Expectations, Gender and Norms in Migration Decision-Making. Population Studies, Vol. 54, No. 3: 307-319.

Dey, Ian. 1999. Grounding Grounded Theory. Guidelines for qualitative inquiry. San Diego: Academic Press.

Engle, Lauren B. 2004. The World in Motion. Short Essays on Migration and Gender. International Organization for Migration. Geneva, Switzerland.

Erel, Umut, Mirjana Morokvasic and Kyono Shinozaaki. 2003. Introduction. Bringing Gender into Migration. In: Morockvasic-Muller, Mirjana, Umut Erel and Kyoko Shinozaki. (eds.): Crossing Borders and Shifting Boundaries. Vol. I: Gender on the Move. International women's university 2000.

Gödri, Irene. 2004. A Special Case of International Migration: Ethnic Hungarians Migrating From Transylvania to Hungary. In: Söderling, Ismo. (ed.): Yearbook of Population Research in Finland XL 2004. The Population Research Institute. Helsinki. Finland.

Hammar, Thomas and Kristofer Thamas. 1997. Why Do People Go or Stay? In: Hammar, Thomas, Kristofer Thamas and Thomas Faist. (eds.): International Migration, Immobility and Development. Multidisciplinary Perspectives. Oxford: Berg.

Hansson, Leeni. 2005. Viron venäjän- ja vironkielisten naisten työ- ja perhesuuntautuneisuuden eroista. [About the Differences Between Estonian and Russian women's work and Family Orientation] In: Työ ja ihminen 19 (2005) 2: 228-238.

Hansson, Leeni. 2001. Networks Matter. The Role of Informal Social Networks in the Period of Socio-Economic Reforms of the 1990s in Estonia. University of Jyväskylä.

Heikkilä, Elli. 2006. International Migration Between Finland and the Baltic Sea Region. Migration letters. An International Journal of Migration Studies. Vol. 3, No. 1, April 2006.

Holstein, James, A. and Jaber F. Gubrium. 1995. The Active Interview. Qualitative Research Methods Vol. 37. A Sage University Paper. Thousand Oaks: Sage Publications.

Huttunen, Laura. 2006. Bosnialainen diaspora ja transnationaali eletty tila. [The Bosnian Diaspora and the Transnational Lived Space] In: Martikainen, Tuomas (toim.): Ylirajainen kulttuuri. Etnisyys Suomessa 2000-luvulla. Helsinki: SKS.

Jasinskaja-Lahti, Inga and Karmela Liebkind. 1997. Maahanmuuttajien sopeutuminen pääkaupunkiseudulla. [The Adaptation of the Immigrants in the Capital Region]. Helsingin kaupungin tietokeskuksen tutkimuksia. 1997: 9.

Jasinskaja-Lahti, Inga. 2000. Psychological Acculturation and Adaptation among the Russian-Speaking Immigrant Adolescents in Finland. Social Psychological Studies. Helsinki: Edita Oy.

Joronen, Tuula. 2005. Maahanmuuttajien elinolot: Olosuhteita ja koettuja elinoloja. [The Living Conditions of the Immigrants: The Circumstances and Experienced Living Conditions]. In: Joronen, Tuula (ed.): Maahanmuuttajien elinolot pääkaupunkiseudulla. Helsinki: Helsingin kaupungin tietokeskus. 
Julkunen, Raija. 1994. Suomalainen sukupuolimalli - 1960-luku käänteenä. [The Finnish Gender Role Model - the 1960s as a Turning Point] In: Anttonen, Anneli, Lea Henriksson and Ritva Nätkin (eds.): Naisten hyvinvointivaltio. Tampere: Vastapaino.

Järvinen-Tassopoulos, Johanna. 2005. Muukalaisuuden labyrintissä. Kreikansuomalaisten naisten matka jälkimoderniin arkeen. [In the Labyrinth of Strangehood - the Journey of Greece's Finnish Women into the Postmodern Everyday Life]. Helsinki: Helsinki University Press.

Kandolin, Irja. 1997. Gender, Work Life and Family Responsibilities in Finland and Estonia. Effects on Economic and Mental Well-being. Finnish Institute of Occupational Health. People and Work. Research Reports 15. Helsinki

Kero, Reino. 1991. Migration Traditions from Finland to North America. In: Vecoli, Rudolph and Suzanne Sinke (eds.): A Century of European Migrations, 1830-1930. Urbana and Chicago: University of Illinois Press.

Kofman, Eleonore, Annie Phizacklea, Parvati Raghuram and Rosemary Sales. 2000. Gender and International Migration in Europe. Employment, Welfare and Politics. London: Routledge.

Kolomainen, Robert. 2003. Kurkistus nyky-Viroon, 1900-luvun alun Helsinkiin ja 300-vuotiaaseen Petroskoihin. [A Glimpse to Today's Estonia, to Helsinki in the Beginning of 20th Century and to the 300-years-old Petroskoi]. Carelia No 6.

Koopmans, Ruud and Paul Statham. 1999. Challenging the Liberal Nation State? Post nationalism, Multiculturalism, and the Collective Claims Making of Migrants and Ethnic Minorities in Britain and Germany. American Journal of Sociology. Vol 103, No 3, (Nov. 1999): 652-99.

Korkiasaari, Jouni. 1989. Suomalaiset maailmalla. [The Finns in the World]. Turku: Institute of Migration.

Kortteinen, Matti. 1982. Lähiö: tutkimus elämäntapojen muutoksesta. [Suburb: A Study of the Changes in Habits of Life]. Helsinki: Otava.

Lammi-Taskula, Johanna. 2004. Äidit työmarkkinoilla - kahden kerroksen väkeä? [Mothers in the Labor Markets - People of Two Layers?] Yhteiskuntapolitiikka 69 (2004):2.

Lie, Suzanne and Linda Malik. 2006. Carrying the Stones: Coping with Adversity. In: Lie, Suzanne, Lynda Malik, Ilvi Jõe-Cannon, and Rutt Hinrikus (eds.): Carrying Linda’s Stones. An Anthology of Estonian Women's Life Stories. Tallinn: Tallinn University Press.

Liebkind, Karmela; Simo Mannila; Inga Jasinskaja-Lahti, Magdalena Jaakkola, Eve Kyntäjä and Anni Reuter. 2004. Venäläinen, Virolainen, Suomalainen. Kolmen maahanmuuttajaryhmän kotoutuminen Suomeen. [Russian, Estonian, Ethnic Finn. The Integration of Three Immigrant Groups to Finland]. Tampere: Gaudeamus.

Lindström, Varpu. 1991. Uhmattaret. Suomalaisten siirtolaisnaisten vaiheita Kanadassa 1890-1930. [The Defiant Sisters. The Stages of Finnish female migrants in Canada 1890-1930]. Porvoo: WSOY.

Lindström, Varpu. 1992. Defiant Sisters. A Social History of Finnish Immigrant Women in Canada. Studies in Ethnic and Immigration History. Toronto: Multicultural History Society of Ontario.

Lukkarinen-Kvist, Marjaliisa. 2006. Tiden har haft sin gång. Hem och tillhörighet bland sverigefinnar i Mälardalen. [The time Has Left Its Trace]. Linköping Studies in Arts and Science No. 372. Linköpings Universitet.

Luo, Guifen. 2005. The Forgotten Dimension: A Case Study of Chinese Female Rural-Urban Migrants and the Social Security Systems in the Context of Modernization. Annales Universitatis Turkuensis. Ser. B, Tom 284. Humaniora. Turku: University of Turku. 
Marsden, Lorna R. and Lorne J. Tepperman. 1986. The Migrant Wife: The Worst of All Worlds. Journal of Business Ethics (pre-1986); Jun 1985. Global: 205.

Massey, Douglas S., Joaquin Arango; Graeme Hugo; Ali Kouaouci; Adela Pellegrino and Edward Taylor. 1993. Theories of International Migration: A Review and Appraisal. Population and Development Review, Vol. 19, No. 3 (Sept., 1993): 431-466.

Mincer, Jacob. 1978. Family Migration Decisions. The Journal of Political Economy, Vol. 86, No. 5 (Oct., 1978): 749-773.

Narusk, Anu and Leeni Hansson. 1999. Estonian Families in the 1990s: Winners and Losers. Tallinn: Estonian Academy Publishers.

Nivalainen, Satu. 2002. Determinants of Family Migration: Short Moves vs. Long Moves. Journal of Population Economic. Springer-Verlag 2004: 157-175.

Oksanen, Annika. 2005. Siirtonaisena Singaporessa. Ulkomaantyökomennukselle mukaan muuttaneen naisen todellisuus. [As a transferred woman in Singapore. The reality of a Woman Who Has Moved to Along to a Command.] Helsinki: University of Helsinki.

Pedraza, Silvia. 1991. Women and Migration: The Social Consequences of Gender. Annual Review of Sociology, Vol. 17. (1991): 303-325.

Phizchkalea, Annie. 2003. Transnationalism, gender and global workers. In: MorockvasicMuller, Mirjana, Umut Erel and Kyoko Shinozaki. (eds.): Crossing Borders and Shifting Boundaries. Vol. I: Gender on the Move. International women's university 2000.

Raghuram, Parvati. 2004. The Difference that Skills Make: Gender, Family Migration Strategies and Regulated Labor Markets. Journal of Ethnic and Migration Studies. Vol. 30, No. 2, March 2004: 303-321.

Raik, Kristi 2004. Viro - euroskeptikoiden maa. [Estonia - the Country of Euro Skeptics. In: Torsti, Pilvi and Timo Vuorela (eds.): 10 uutta tulijaa. Euroopan unioni - eriaisia yhdessä. Ulkoasiainministeriö/Eurooppa-tiedotus. Helsinki.

Rantalaiho, Liisa 1994. Sukupuolisopimus ja Suomen malli. [Gender Role Contract and the Model of Finland]. In: Anttonen, Anneli, Henriksson, Lea ja Nätkin, Ritva: Naisten hyvinvointivaltio. Tampere: Vastapaino.

Reuter, Anni and Magdaleena Jakkola, Magdaleena. 2005. Venäjänkielisten, vironkielisten ja kaksikielisten maahanmuuttajien sosiaaliset verkostot. [The Social Networks of Russian, Estonian and Bilingual Immigrants]. Teoksessa: Paananen, Seppo (toim): Maahanmuuttajien elämää Suomessa. Helsinki: Tilastokeskus.

Ruckenstein, Minna. 2004. Työpaikkana maailma. Lähtijöiden näkökulmia globaaliin talouteen. [The World as a Working Place. The Starter's Point of Views for the Global Economy]. Helsinki: Edita.

Sassen, Saskia. 1999. Guests and Aliens. New York: The New Press.

Siddiqui, Tasneem. 2003. An Anatomy of Forced and Voluntary Migration from Bangladesh: a Gendered Perspective. In: Morockvasic-Muller, Mirjana, Umut Erel and Kyoko Shinozaki. (eds.): Grossing Borders and Shifting Boundaries. Vol. I: Gender on the Move. International women's university 2000.

United Nations 1998. International Migration Report. Department of Economic and Social Affairs. ST/ESA/SER.A/20. New York.

Vertovec, Steven. 2004. Trends and Impacts of Migrant Transnationalism. Working Paper No.3, Centre on Migration, Policy an Society. Oxford: University of Oxford.

Zechner, Minna. 2002. WP4 Care arrangements in immigrant families. National report: Finland. SOCCARE Project Report 4.1. Contract No. HPSE-CT-1999-00010. 
Zechner, Minna. 2006. Hoivan paikat transnationalisissa perheissä. [The Place of Care in Transnational Families] In: Martikainen, Tuomas (toim).: Ylirajainen kulttuuri. Etnisyys Suomessa 2000-luvulla. Helsinki: SKS.

Ågren, Marja. 2006. "Är du finsk, eller...?" En etnologisk studie om att växa upp och leva med finsk bakgrund i Sverige. ["Are you Finnish or..." An Ethnographic Study of growing up in Sweden with a Finnish Background] Arkipelag group Göteborg.

\section{Electronic References:}

Alien Law. 48§. Admitting the Permit of Residence for a person coming from the area of Former Soviet Union. [Online]. [Cited 5 July 2006] Available at: $\leq$ http://www.finlex. fi/fi/laki/alkup/2004/20040301>

Finlex (Electronic Legislation of Finland). 2005. HE 221/2005. [Online]. [Cited 7 August 2006]. Available at: $\leq$ http://www.finlex.fi/fi/esitykset/he/2005/20050221>

Granquist, Mark A. 2006. Estonian Americans. [Online].[Cited 8 Aug 2006]. Available at: $\leq$ http://www.everyculture.com/multi/Du-Ha/Estonian-Americans.html $>$

Kodakondsus- ja migraatsioniamet. 2004. [Citizenship and Migration Board] The Start of the Documentation of the Population of the Republic of Estonia. [Online].[Cited 8 Aug 2006]. Available at: $\leq$ http://www.mig.ee/eng/CMB/history/ $>$

Korkiasaari, Jouni. 2003. Suomalaiset maailmalla - katsaus Suomen siirtolaisuuteen kautta aikain. [The Finns in the World - A survey of Finnish Migrants Throughout the Times]. The Migration Institute. [Online]. [Cited 5 July 2006]. Available at: $\leq$ http://www.migrationinstitute.fi/db/articles/art.php?artid=3>

Korkkalainen, Sari. 2004. Globaalit suomalaisverkostot. Tarvekartoitus ulkomailla asuvien suomalaisten ja Suomeen palanneiden sosiaalisen pääoman verkottamisesta suomalaisyritysten käyttöön. [Global Finnish Networks. Surveying the Needs of Networking the Social Capital to the Use of the Finnish Companies of Finnish Living Abroad and of Those Who Have Returned to Finland.] Web reports 4. The Migration Institute [Online]. [Cited 1 March 2005]. Available from: $\leq$ http://www.migrationinstitute.fi/db/articles/art. php?artid $=84>$

Ministry of Social Affairs in Estonia. 2006. [Online]. [Cited 20 April 2006]. Available from: $\leq$ http://www.sm.ee/est/pages/index.html $>$

Niessen, Jan, Yongmi Schibel and Cresside Thomson. 2005. Current Immigration Depates in Europe: A publication of the European Migration Dialogue. [Online][Cited 4 July 2006] Available at: $<$ http://www.migpolgroup.com/multiattachments/3043/DocumentName/ EMD Greece 2005.pdf $>$

Social Insurance Institution of Finland. 2005. [Online]. [Cited 22 March 2005] Available from: $\leq$ http://www.kela.fi/in/internet/suomi.nsf/Docs/110701111752EH?OpenDocument/>.

Statistics Finland. [Online]. [Cited 20 April 2006]. Available from: $\leq$ http://tilastokeskus.fi/til/ vaerak/2005/vaerak_2005 2006-04-13 tie 001.html>

\section{Other References:}

Ahlqvist, Tony. 1998. Inkerinsuomalaiset maahanmuuttajat Virossa toisen maailmansodan jälkeen. [The Ingrian Finnish Immigrants in Estonia After the World War II] Opinnäytetyö. [Master Thesis]. University of Helsinki.

Tauriala, Seppo 2005. Personal Communication with the Consul of Finland, 16.4.2005 at the Consulate. 


\section{Appendix 1. The Original quotations in Finnish.}

(1) 'Mun ensimmäinen reaktio oli semmoinen, että ei missään tapauksessa, minähän en Viroon muuta. (naurahtaa) [---] ... se oli ihan niin kuin et tämä on ihan kehitysmaa, että mä en missään tapauksessa halua muuttaa sinne. Että ajatus oli, että se on samantyyppinen kun Venäjälle lähtisi."

(2) 'Mie luin semmoisen artikkelin tästä Tartton yliopistosta lehdestä [---] suomalaiset opiskelijat oli kirjoittanut sen, ja se kuulosti niin kun maailman mageimmalta [---] ja mie olin että yes"

(3) '”...mä olin käynyt täällä itse asiassa kerran silloin kun oli vielä neuvostovalta vielä voimassa. Ja silloinhan täällä oli ihan erillaista ... ei ollut mitään. Kaupoissa oli tyyliin kokista ja lihaa... ja asunnot oli mitä oli, mäkin asuin perheessä. Ja silloin kun mä lähdin tänne, niin mulla oli viisi pakettia tamppooneja kassissa ja kaikki tämmöiset perusjutut, koska mä ajattelin, että täällä ei oo.”

(4) '”...että silloin aluksi kun lähti ja tuli tänne, niin kuvitteli suurin piirtein, että auto varastetaaan heti seuraavana yönä siitä kadulta. [---] ...vieläkin on semmoinen tietty turvattomuus vielä, niin kuin lasten suhteen, että... että... jos mä annan heidän kaupassa mennä sinne leluosastolle ja kierrän itse ihan rauhassa, niin se, mutta aluksi niitä ei uskaltanut jättää yhtään mihinkään. [---] Mutta autoon heitä ei voi missään tapauksessa jättää täällä.,"

(5) 'Sitten mulla oli joku äitikompleksi itselläni (naurahtaa) [---] Eli mulla oli hirveän hallitseva oma äiti. Joka aina... hänellä piti muun muassa aina olla avain mun asuntoon, hän avasi mun postit ja kaikkea. Ja mä totesin, että kun mä lähestyn neljääkymmentä, niin mn täytyy päästä äidistäni irti. Ja mä en nähnyt siihen muuta keinoa [kuin muuttaa ulkomaille], koska mä kuitenkin haluun säilyttää välit häneen."

(6) '...ensimmäisen puolen vuoden aikana oli kaikkein vaikeinta se sopeutuminen. Silloin mulla oli hirveä koti-ikävä. [---] ...se nainen sanoi, että joo, tuo on ihan tuttua, että sulla on alussa tuommoisia tunteita, mutta hän ihan rupesi viihtymään täällä. Mä ajattelin, että voi ei, mä en usko, että semmoinen vaihe tulee. Mut reilu puoli vuotta siinä meni ja mä aloin vähitellen viihtyä täällä..."

(7) ’joo, ja oikeastaan niin kun sit kun mie päätin jäädä pidemmäksi aikaa, [--], niin sitten tuli se kulttuurishokki (naurahtaa), mitä siihen mennessä ei ollut tullut. [---] niin sit niin kun tuli jotain semmoisia, tai huomasi niitä negatiivisiakin puolia yhteiskunnassa. Et kun siihen asti oli jotenkin silleen hirmu po- 
sitiivisesti suhtautunut kaikkeen silleen tutkivasti. No silleen, vähän niin kun turistina alussa."

(8) '...oikeastaan se kuvio toimii sillä tavalla, että hän tekee etätyönä sitä työtä, mitä hän suomestakin käsi teki. [---] että se on suhteellisen helppo tilanne."

(9) "...sitten mä olin äitiyslomalla niin kun aika moni tänne tulleista äitiyslomalla ja siinä olin työn ohessa opiskellut ja sitten mä ajattelin, että nyt on hyvä sauma lähteä ja sitten toisaalta on tavallaaan hyvä jäädä kotiinkin vähäksi aikaa, voi sitten saattaa loppuun opintoja."

(10) "No mä olin tehnyt paljon töitä, et se... sanotaan, että ennen lapsia mulla oli kolme eri työpaikkaa... [---] et sitä työtä niin kun oli tosi paljon ... et sitten kun mä jätin ne työt, ja aloin niin kun perhe... kotirouvaksi, niin sehän oli yleellisyyttä... kerta kaikkiaana [---] se tuntui lomalta... nyt mä lähden lomalle ja se on pitkä..."

(11) "Siitä oltiin sitten puhuttu kyllä aiheesta. Musta siitä oli ihan kiva leikkinä puhua, mutta sitten kun hän yhtenä päivänä tuli kotiin, ja sillä oli A4, että lupa myönnetty muuttoon, niin siinä vaiheessa tuli mulle itku kurkkuun (naurahtaa). [---] Mä olin lopultakin saavuttanut sen, minkä mä olin halunnut, että hyvä työpaikka, ja työ mitä rakastin."

(12) "...silloin kun mä muutin pois, niin silloin oli semmoinen tunne, että nägemiste Eesti, että tänne mä en enää tule takaisin. Mutta sitten kun me oltiin hetken aikaa oltu Suomessa, niin sitten mä rupesin [---] miettimään, että mä en enää ikinä mene Eestiin. [---] Mutta mä olin päättänyt, että minähän en rupea pientä lasta Viroon raahaamaan, että nyt me asutaan Suomessa, että täällä tai siis siellä on turvallisempaa ja muuta. [---] Mutta sitten täällä tuli yksi paikka auki ja mä sitten hain sitä. Ei eikä tarvinnut sitten edes mitään pitkää harkintaa, vaan se tuli heti, että tuo on mun paikka."

(13) '..meillähän oli niin kuin tosi hyvä tilanne, että mun isoäiti oli töissä semmoisessa merimiessairaalassa [---] ruokavarastovastaavana [---] ja hänellä oli mahdollisuus siihen, että me saatiin aina hyvät ruoat ja näin [---] ja sitten kun oli se suomalainen isäpuoli, niin hän tietysti hankki meille kaikki vaatteet ja sen tyyppiset [Suomesta]. [---]Että vaikka sulla olisi ollut rahaakin, mutta kun jos sulla ei ollut suhteita, niin sulla ei ollut mitään. [---] Että meillä oli niin kuin silleen hyvä tilanne, mutta olihan sitten niin kuin esimerkiksi eläkeläiset ja tämmöiset ... tai siis semmoinen epävarmuиs." 
(14) 'Ja sitten kun mä tulin Tarttoon -92 töihin, niin siihen aikaan oli vielä se, että leipää sai kaupasta kupongilla ja että kun kaupan oven takana oli pitkä jono, piti mennä sinne jonon perälle, että sieltä saa nyt jotakin. Jotakin hyvää. [---] Että kauppaan oli tullut jotakin, esimerkiksi vessanpaperia."

(15) 'Että sä joko tulet ja menet naimisiin. Pakkonaimisiin. Pakko oli mennä naimisiin, että sä pääset pois sieltä. Ja isä halusi tietysti elää lastensa kanssa. Että sitten mun oli pakko mennä naimisiin, kun enhän mä muuten olisi päässyt pois sieltä.

(16) 'Se, se on semmoinen, nyt jälkikäteen ajattelee, että se oli paljon semmoinen, että mä halusin jossain olla rauhassa, että ei ole niin kuin jokapäiväisiä huolia, tai niitä olisi ainakin vähemmän."

(17) 'Meillä ei ollut [Virossa] huonekaluja puhumattakaan mistään muusta. Mutta me oltiin aika tyytyväisiä. [---] Mutta kun lapsi sairastui aika vakavasti ja päätettiin, että kun elämä tarjoaa tällä hetkellä semmoisen mahdollisuuden että muuttaa muualle... Oltiin nuoria ja rohkeita ja päätettiin, että miksei voisi kokeilla. Et jos emme tykkää, tullaan takaisin. Kun mun äiti ja isä asui siellä ja meillä on vieläkin asunto tallessa."

(18) "Mä en olisi halunnut muuttaa alusi. Tai silloin mä olin sitä mieltä, että mä en halua muuttaa mihinkään maahan, missä mä en osaa kieltä. Se on hirveen orpo olo.."

(19) "Oikeastaan täti pyysi mua silloin. [---] Hänellä oli itsellä poika [---] mutta se ei alunnut lähteä. [---] Ja mun veli tuli silloin kanssa mukaan. [---] Ja mun sisko tuli, oliko se nyt puoli vuotta myöhemmin. [---] Ja sitten mun vanhemmatkin tuli jossain vaiheessa..."

(20) 'En edes osaa sanoa, oliko mulla odotuksia. Mun mielestä silloin oli tärkeintä se, että mulla on työpaikka, ja että... vaan, että mulla on työ, ja että saan rahaa, että voi vaan elää ihan normaalia elämäää. [---] Mutta koska mä halusin tehdä just tätä työtä, eikä mitään muuta, ja hyvin vaikea oli löytää Virosta töitä yleensä, niin... niin oli ihan pakko tulla."

(21) ”...isoäidin kaverit lähetti isoäidille Anna -lehteä ja Kotiliesi - lehteä. [---] Mulla kerran oli ne yläasteella koulussa mukana ne lehdet, nïn revittiin käsisitä (nauraa). Et opettaja pyysi, et saisko hänkin katsoa sitä lehteä..." 
(22) "Kyllä täällä aluksi oli rankkaa. Ei sille voi mitään. [---] Oli maanantai ja mulla oli 40 markkaa siksi viikoksi. Mä tiesin, että kouluruoka maksaa kympin, että neljäksi päiväksi mulla on ruokarahaa, että yksi päivä mun täytyy olla nälissäni, kun mulla ei ollut ruokarahaa."

(23) '....mieheni sai työpaikan [---] niin minusta tuntui ihan, että mä en ole hyödyllinen tähän yhteiskuntaan, et kun mä en voinut mitään tehdä et kun mulla ei ollut työpiakkaa että kun mä sain sossusta [rahaa] et se jotenkin hävetti et ei ollut hyvä... kun kavereita ei ollut ja oli semmoinen tosi hankala hetki."

(24) "Virossa mulla meni aika hyvin, mä olin [ammatti] ja mulle tarjottiin parista eri paikasta aika hyvää työpaikkaa. Ja sitten tulla vapaaehtoisesti Suomeen työttömäksi niin kuin ilman minkäänlaista tulevaisuutta..."

(25) '...että tunsi itsensä ihan niin kuin vieraaksi niin kuin siinä mielessä, että tuntui, että [koulu] olisi voinut panostaa enemmän tähän kielitietouteen."

(26) 'Oli se alku pikkaisen vaikeata. [---] Kun ei ollut yhtään ystävää. Semmoinen ... puuttui semmoinen sosiaalinen kanssakäyminen. Kun oli tottunut Virossa elämään tavallaan ... että sitten joutui tavallaan aloittamana uudelleen alusta..."

(27) "Että siis se kieli oli niin kuin, mutta mä puhuin väärin. Mutta että enemmän sellaista lähiohjausta tai sellaista mä olisin tarvinnut. Mutta kyllä mä pärjäsin.”

(28) "Ja se jono oli puoli vuotta, se [oleskeluluvan] uusimisjono. Ja passit otettiin pois, ei päässyt lähtemään minnekään, niin se mua ahdisti silloin, ihan suunnattomasti. [---] Sä et pääse minnekään, sä olet yksin. Tuli itkettyä paljon. [---] Ja sen takia mä meninkin niin nopeasti kuin mahdollista yliopistoon ja töihin, että mä pääsin siitä vankeudesta." 
